\title{
Tércio Sampaio Ferraz Júnior Saúda o Novo Diretor
}

Cabe-me a honra, neste momento, de dirigir-lhe a palavra para saudá-lo em nome da Congregação da Faculdade. Não são poucas, afortunadamente, as vezes em que nos sentimos, nesta Casa, prisioneiros voluntários de suas tradições. A posse solene do seu diretor é uma dessas ocasiões, em que a oportunidade se oferece para o fortalecimento, no presente, do passado que nos acompanha.

$\hat{E}$ quase um truismo afirmar que a velha Academia do Largo de São Francisco é, pedra sobre pedra, feita de tradição. Repetida nas trovas dos seus poetas, na palavra dos seus oradores, na voz dos seus mestres e alunos, a tradição que muitas vezes se louva e se cultua, nem sempre, contudo, é entendida no sentido mais profundo que deixa em todos que por aqui passam a sua marca indelével. $\mathbf{E}$ por isso há os que, vendo nela apenas a poeira do tempo e os preconceitos do passado, a cobrem de ridículo, mal percebendo que não é a tradição que agridem, mas a si próprios.

$\mathrm{Na}$ verdade, no entanto, não é por sua culpa que o fazem. De certa maneira, pode-se dizer que o mundo de hoje perdeu o sentido para a tradição, que se tornou para ele apenas um relicário que se guarda e se conserva, um mero hábito que se repete, dando à tradição a imagem de um conservadorismo sem razão, um uso que ninguém mais usa, um traje que ninguém mais veste, um simbolo que ninguém mais entende, uma voz sem mensagem para o presente e sem perspectivas para o futuro. Tradição parece a muitos um túmulo que melhor faria se se recolhesse no seu silêncio e apenas testemunhasse a passagem do que já foi e que não tem mais porque voltar.

Esta Casa de Ensino, por dedicar-se ao Direito, sabe, no entanto, mais do que as outras, o que deve entender por tradição. Pois dedicando-se à cultura jurídica, tal como ela chegou até nós a partir da experiência romana, aprendeu desde cedo que a tradição, antes de tudo, é o fio condutor através do passado ao qual cada nova geração, intencionalmente ou não, liga-se em sua compreensão do mundo e em sua própria experiência. Nestes termos, tradição não é um conceito romântico, uma mera glorificação do passado, mas algo que assinala, em cada momento do presente, o sentido das transformações do mundo em que se vive e as circunstâncias em que a confiança inquestionada 
nos valores exigem dos homens uma nova tomada de posição, Tradição, assim, não é submissão ao poder tirânico de noções e usos cedidos e puidos, mas uma força viva que, transformando-se, jamais perde a memória das suas origens.

Vossa Excelência, entretanto, Prof. Marotta Rangel, assume a direção desta Faculdade, no momento em que o caos de complexidades no palco político, econômico, social e jurídico parece provocar uma quebra na força orientadora da tradição. A sociedade de massas, como um fato estabelecido, que, em seu ineditismo, não pode ser compreendida mediante as categorias usuais do pensamento, quebrou o sentido dado pela tradição e instaurou a funcionalidade dos significados. O fim das tradições, sobretudo num país novo como o nosso, faz com que a vida seja entendida como um jogo tecnológico, que não resulta da escolha deliberada de ninguém, mas está sujeita às razões superiores da funcionalidade. Vivemos num estado de dúvida permanente e o salto da crença para a dúvida e da dúvida para a crença torna-se algo absolutamente normal, que atinge não apenas a religião, mas a política, a economia, a própria ciência e por último, mas não menos importante, o direito. Com facilidade passamos do relativismo à crença-sem-discussões e desta à imposição tirânica de opiniões que se vestem com os trajes tecnológicos das verdades indisputáveis. Por isso mesmo, contudo, passamos também desta crença monolítica ao nihilismo exacerbado e cínico. Como se nada mais existisse, vivemos um paroxismo em que ou tudo vale ou nada vale. Se tudo vale, então que se calem os outros. Se nada vale, então tudo é questão de oportunismo.

O mundo sem tradição é um mundo que não preserva o passado, em que uma geração não lega mais a outra o testemunho dos antepassados, um mundo que desdenha padrões e modelos consagrados pelo tempo, que troca e supõe substituir com vantagem a sabedoria e a prudência pela técnica e pela esperteza. De fato, o mundo de hoje é um mundo que vê seus problemas sociais como uma questão de organização de quadros técnicos e profissionais; seus problemas econômicos como questão de produção planificada; seus problemas políticos como questão de descobrir mecanismos de controle da presença das massas no Estado. A experiência humana torna-se um jogo de estímulos e respostas que podem ser racionalizados. Daí a relação tornada meramente pragmática do homem com o seu mundo, pois vendo ele o mundo apenas como um problema, transforma sua ação em pura decisão, ou seja, numa opção técnica que deve modificar-se de acordo com os resultados e cuja validade repousa no seu bom funcionamento. Com isto, no entanto, ocorre essa progressiva perda do senso comum e a dissolução dos valores que a tradição ali preservava, o que explica afinal um certo vazio espelhado na ausência ou na relativização de padrões últimos de julgamentos, de bases seguras para a própria adoção de decidir. 
Juridicamente podemos falar então na tecnicização do direito. Direito, neste quadro, parece apenas o que é posto por decisão, mais ainda, aquele cujas premissas da decisão que o põe também são postas por decisão. Ora, se tudo é fruto de uma decisão e se decisões não se julgam, mas se controlam dentro de estruturas burocráticas, então o direito só pode ser visto como um mero instrumento viabilizador de projetos. É a ética da eficiência que acaba por obscurecer os valores jurídicos da tradição, reduzindo as questões da Justiça, da distribuição dos bens e das riquezas; da eqüidade e do bem-estar social à funcionalidade dos planos concebidos nos âmbitos desta poderosa abstração de nossos dias: o Estado burocrático.

É claro que o direito assim concebido é um instrumento ágil nas mãos de quem domina. Sem as peias da tradição, ele modifica as situações, instaura, restaura e elimina as ordens, ao sabor das necessidades do controle social exercido superiormente. E é óbvio que não falamos aqui de nenhuma abstração pois qualquer jurista bem informado sabe como as penadas do legislador não poupam tintas nem temem a inflação das normas, que fazem com que as leis se submetam a regulamentos e as constituições às portarias, quando a necessidade de resolver os problemas do país se sobrepõem pragmaticamente às instituições tradicionais e ao respeito que elas produziam.

Talvez uma das principais diferenças entre as sociedades que se guiam pela tradição e a sociedade pragmática de nossos dias esteja em que aquela sentia necessidade do direito, valorizava e desvalorizava os direitos ao transformá-los, até usava e abusava deles, porém não os criava, não produzia o direito. A sociedade pragmática, ao contrário, não precisa do direito, precisa de normas e os produtos normativos oferecidos pelas máquinas burocráticas do Estado são produtos como qualquer outra mercadoria: têm valor de uso e têm valor de troca, mas não têm valor em si.

Somos hoje propensos a crer que, no âmbito jurídico, tudo está regido pelas relações de meio e fim e não pela presença inevitável do outro. O direito se torna, assim, um objeto de monólogo, reduzindo, cada vez mais, o espaço do diálogo. Ele não perde o seu caráter público, no sentido de social, mas perde o seu sentido de prudência, pois sua legitimidade deixa de repousar na concórdia potencial dos homens, para fundar-se numa espécie de coerção: a coerção pela eficácia funcional.

Esta situação, como se pode imaginar, não deixa de repercutir no âmbito das instituições de ensino. Ainda recentemente a Ordem dos Advogados do Brasil dirigiu-se ao Ministro da Educação para lançar, mais na forma de um repto do que um projeto, um documento em que protesta contra as condições a que foi reduzido o ensino do direito. É importante notar que, em suas observações, a $\mathrm{OAB}$ se indigna sobremaneira com o tratamento tecnicista que muitas faculdades dão à educação jurídica de nossos universitários. Substituímos a pretensão 
a um ensino retoricamente humanista por um saber pretensamente especializado, que vê na ciência do direito uma técnica imediatista, uma arte de saber fazer sem se preocupar em saber porque. Nestes termos razão assiste à $\mathrm{OAB}$, pois, não se pode negar que, para os estudantes de direito hoje no Brasil, a formação do bacharel, na maioria das faculdades, é entendida como uma acumulação progressiva de informações, limitando-se o aprendizado a uma reprodução de teorias que parecem desvinculadas da prática ou à memorização de esquemas prontos de especialização duvidosa, que vão repercutir na imager: do profissional como um técnico a serviço de técnicos. Em outras palavras, como disse certa vez Santiago Dantas, proporciona-se ao estudante "conhecimento descritivo e sistemático dos textos juridicos, desvinculados de seu contexto sócio-econômico e político e dos conflitos de interesses que lhe deram origem".

Não é rósseo o quadro do ensino jurídico em nosso país. $\mathrm{O}$ crescimento desmedido do número de estabelecimentos autorizados ou reconhecidos, hoje mais de 137 , não foi acompanhado pelo igual preparo de docentes aptos a cumprir a função do magistério nem pela capacidade do mercado de trabalho em absorver os bacharéis que se formam hoje em número superior a 20.000 por ano. As metodologias de ensino que se utilizam permanecem atreladas a formas eficazes quando o país não tinha mais do que 25 mil estudantes de direito, mas francamente desiquilibradas quando superamos a casa dos 100 mil, provocando a sobrecarga das classes e inviabilizando o controle efetivo do aproveitamento.

Esta situação, embora seus problemas não lhe sejam exclusivos, sendo, ademais, persistentes de longa data, tem colocado o ensino jurídico numa verdadeira armadilha. De um lado, propicia-se uma visível distorção no sistema universitário, no qual as faculdades de Direito, pelo baixo custo de funcionamento e alta absorção de estudantes, acabam por atuar como cobertura das deficiências do referido sistema, perdendo, assim, para outras carreiras em termos de qualidade. De outro lado, porém, isto gera uma visível queda na formação profissional, que repercute nos serviços oferecidos à comunidade. Ou, como disse um ilustre professor desta Casa, Mauro Brandão Lopes, "no ensino, a imprecisão de conceitos e a incongruência interna da massa amorfa das leis brasileiras, aliadas ao despreparo dos alunos, produzem maus juristas e os produzem em grande quantidade. Ora, os maus juristas são maus legisladores, e enxertam nas leis a sua má formação conceitual; os maus juristas são maus juizes, e traduzem leis más em pior jurisprudência; e, ainda mais sério, os maus juristas são maus advogados, e fazem de sua profissão a busca contínua de meios e modos, não propriamente de burlar os objetivos de leis boas, mas de usar as más contra adversários dedicados à mesma tarefa, fazendo lutas desleais das lides forenses, em que todas as manobras não só são possíveis, como são mesmo esperadas, e muitas vezes elogiadas". 
Com isso, no entanto, levamos o próprio direito a uma situação paradoxal. Como é sabido e repetido de longa data, criar condições de segurança para a vida em comunidade é um dos atributos essenciais do direito. Onde este é claro e delimitado, criam-se as condições de certeza e igualdade que habilitam o cidadão, a sentir-se senhor dos seus próprios atos e dos atos dos outros. O direito instaura segurança ao garantir, assim, o câmbio das expectativas. Segurança jurídica significa pois, a clara determinação e proteção do direito contra o não-direito. A situação contudo, a que estamos sendo conduzidos pela mentalidade utilitarista e burocrática da coisa jurídica e pelo seu ensino deteriorado em seus objetivos está criando, para a sociedade em que vivemos, um novo tipo de insegurança para a qual o direito não tem resposta: é a insegurança gerada pelo próprio direito! O direito, é verdade, continua a discriminar entre o proibido e o permitido, o obrigatório e o facultativo, continua, assim, a proteger o cidadão integro do que lhe ofende a moral, a proteger-nos contra o furto, a apropriação indébita. Mas que significa para o cidadão a insegurança de um assalto, contra a insegurança ditada, por exemplo, pela falência de uma instituição financeira que, dentro de todas as normas e conforme todos os direitos, lhe corrói as parcas economias e o põe nas malhas da Justiça que, manobrada como foi descrito por Mauro Brandão Lopes, o reduz à impotência e ao desamparo?! Que significa a insegurança de uma agressão física, se comparada com a discricionariedade política na interpretação da Constituição, que, invertendo o papel da Carta Magna, ao invés de fazê-la baliza dos atos políticos, torna os atos políticos a baliza do seu entendimento, a ponto de ser preciso saber como agem os governantes para saber então o que a Constituição poderá prescrever?

A insegurança gerada pelo próprio direito é, sem dúvida, a mais dura e perniciosa conseqüência da crise do direito e do ensino. Ela produz descrédito, desconfiança, sem que se encontre, a longo prazo, uma saída. Apela-se, então, no plano do ensino, para ideais vagos e abstratos, que mal escondem a insatisfação das necessidades mais simples, porque exigem renúncias e prejuízos momentâneos que ninguém vê como serão compensados. E apela-se, no plano do direito, para objetivos instrumentais que, ao invés de garantí-lo, ainda mais o deterioram.

Perdoe-me, Senhor Professor Marotta Rangel se, ao saudá-lo, proponho-lhe este quadro de crise. Uma crise, no entanto, nos obriga a voltar às questões mesmas e exige respostas novas ou velhas, mas de qualquer modo julgamentos diretos. Uma crise só se torna um desastre quando respondemos a ela com juízos pré-formados, isto é, com preconceitos. Uma atitude dessas não apenas aguça a crise como nos priva da experiência da realidade e da oportunidade por ela proporcionada à reflexão.

Por mais claramente que um problema geral possa se apresentar em crise, ainda é impossivel chegar a isolar completamente o elemento universal das circunstâncias específicas em que ele aparece. Embora 


\section{4}

a crise do direito e do seu ensino possa afetar todo o mundo, é significativo o fato de o encontrarmos numa forma aguda entre nós. $\mathrm{E}$ a razão é que, talvez, por mais estranho que isto pareça, é justamente entre nós que uma crise no direito pode-se tornar realmente um fator na nossa vida política.

No Brasil, como nos mostra a sua tradição, o direito e o seu ensino desempenharam sempre um papel incomparavelmente mais importante do que os outros fatores. Num certo sentido, pode-se dizer que a independência brasileira e o espírito constitucionalista, por exemplo, nasceram de um mesmo parto. O movimento de idéias que marcou o Iluminismo do século 18 nos empurrou para a liberdade, fazendo prevalecer, concomitantemente, o respeito aos direitos individuais e às suas garantias. É verdade que, em muitos aspectos, a revolução burguesa que acontecera na França ficou por ser feita entre nós. De qualquer modo, porém, é importante fixar que o Brasil surgiu como nação independente sob a égide de um regime constitucional. Além do mais, com uma população predominantemente européia, o país pode, desde cedo, assistir a transferência de modelos jurídicos da metrópole portuguesa, com instituições típicas como o contrato e a propriedade, que logo se localizaram no centro da vida econômica e social do país, o que evitou que o sistema legal se tornasse mera peça de museu. Pois, ao contrário, de algum modo, com todas as dificuldades, isto reforçou nossos valores sociais básicos, criando nossa própria tradição. Daí a produção de obras de grande peso na formação nacional, como o Código Civil de 1916, que, embora refletisse um pensamento jurídico mais avançado, não deixou de marcar e de influenciar profundamente a estrutura e o desenvolvimento das relações entre nós.

Os juristas, desde o século 19, não foram apenas o que se poderia chamar hoje pseudoprofissionais do direito. Muito mais do que isso os bacharéis, como classe, foram elementos destacados nas instituições do país, como legisladores, administradores, diplomatas, liberatos. Neste sentido, a Faculdade de Direito, criada em 11 de agosto de 1827, desempenhou desde cedo um importante papel na formação da tradição nacional. Colaborando na elaboração das leis, produzindo doutrinariamente uma organização jurídico-legal da vida política, ela representou uma importante força em favor do Estado de Direito, ou seja, aquele Estado marcado por limitações constitucionais ao poder governamental e que assegura áreas de autonomia à vida privada.

Esta mentalidade jurídica, com todos os percalços e fantasias que gerou e trazia consigo, foi, de algum modo, uma das grandes heranças de nossa tradição. Veiculada continuamente na palavra dos mestres e estudantes desta Casa, ela gerou o Segundo Império, libertou os escravos, proclamou a República, foi revolucionária em 24, 30 e 32, derrubou a ditadura de Vargas em 45 e alimentou, em parte, até alguns programas políticos de 64 . 
Pois bem, Senhor Professor Marotta Rangel, é em nome desta tradição e da responsabilidade que ela nos confere como instituição que o saúdo como o novo Diretor da Faculdade. Vossa Excelência, porque é um emérito jurista, professor dedicado ao ensino e à pesquisa, sabe certamente destas coisas, conhece as dificuldades e não desconhece as responsabilidades. Como homem ligado ao estudo e à prática do Direito Internacional, sabe ademais quão importante é o diálogo e a franqueza no trato dos conflitos e dos problemas. $\mathrm{O}$ vigor e a continuidade da tradição desta Escola têm, seguramente, em Vossa Excelência um depositário fiel, que saberá conduzir-nos nos meandros de uma crise que, se não está em nosso poder resolver, cabe a nós procurar para ela as respostas necessárias. Para isso possui Vossa Excelência aquele traço proeminente do jurista, a gravitas dos romanos, a capacidade de arcar com essa responsabilidade e que pode atuar, nas palavras de Plutarco, "como um peso central que, à maneira do lastro em uma embarcação, mantém as coisas sempre no justo equilibrio". Nós confiamos em Vossa Excelência.

Obrigado. 